\title{
Gullele Botanic Garden, Addis Ababa (Ethiopia): current status, challenges and opportunities
}

\author{
Talemos Seta' \& Birhanu Belay ${ }^{2}$
}

\begin{abstract}
Gullele Botanic Garden (GBG) was founded through a joint venture between Addis Ababa University and Addis Ababa City Government. Since its establishment in 2010, it has developed its infrastructure and carried out a range of activities related to plant conservation, research, environmental education and ecotourism in line with its vision and mission. Key activities described in this paper are the five different uses of GBG land; the installation of a weather station; and the construction of a mini-greenhouse for plant acclimatisation, the multipurpose Agora II (an eco-friendly building with a green roof), a thematic garden and a nursery. The lists of endemic plants (65), large mammals (11) and endemic bird species recorded are presented in Appendices I, II and III respectively. The main activities and works carried out by GBG are not yet widely known to local and international communities. Through describing the garden's current status, challenges and opportunities, this paper aims to increase awareness among the scientific community and more widely of GBG's activities and intentions for protecting Ethiopia's flora.
\end{abstract}

\section{Background}

Botanic gardens are a major force for the conservation of a variety of plants and are more than public parks. They have a scientific basis for one or more aspects of their work and are also involved in activities that use biodiversity to promote human wellbeing. The collections of living plants are documented for the purposes of scientific research, conservation, display and education (Gratzfeld, 2016). The GardenSearch database ( $\mathrm{BGCl}, 2021)$ has information on more than 3,700 botanical institutions worldwide. It has been estimated that at least 105,634 species (30 per cent of all plant species diversity) and over 41 per cent of known threatened species have been conserved by 3,269 botanical institutions in 180 countries around the world (Mounce et al., 2017). Among many other purposes, botanic gardens offer the opportunity to conserve plant diversity $e x$ situ and play an important role in preventing species extinction through integrated conservation action (Mounce et al., 2017).

Many botanic gardens are focused on research for conservation and economic botany, for commercial and local benefit, and many of the world's globally threatened plant species are represented in their living collections or seed banks. The living

\footnotetext{
${ }^{1}$ Talemos Seta is a former Lead Researcher in Ecology and Conservation at Gullele Botanic Garden, and is now Assistant Professor in Plant Biology and Biodiversity Management at Dilla University, Ethiopia.

Address: Department of Biology, Dilla University, Dilla, Ethiopia.

Email: talemos.seta@yahoo.com

${ }^{2}$ Birhanu Belay is Senior Researcher in Botany at Gullele Botanic Garden, Addis Ababa, Ethiopia.

Email: birhanubelay79@gmail.com
} 
collections or seed banks collectively provide an insurance policy supporting the maintenance of global biodiversity (Smith, 2018). It is important that botanic gardens with less cultivated landscapes maintain them with an ecological remit both to be attractive and to create a balance between nature and human activities. Botanic gardens should be relevant for the community, establish a network of natural areas and provide an attractive environment so that the scenery can be enjoyed and appreciated (Kithiia \& Lyth, 2011). In addition to the above roles, botanic gardens have staff with the skills and expertise to study and manage plants in cultivation and in the wild, so as to make a major contribution to ecological and human wellbeing.

For the past three and a half decades, there has been a strong interest among the research community in Ethiopia in establishing a botanic garden as a site for the repository of plant species. This interest was realised in $\mathbf{2 0 1 0}$ with the opening of Gullele Botanic Garden (GBG). It was recognised that a botanic garden would create favourable conditions for the management of biological and natural resources and would lead to opportunities for education and research in an environmentally protected area. And so GBG began as a joint venture between Addis Ababa City Government and Addis Ababa University.

The garden extends over 705 ha and is located in the north-west of the city. GBG's Management Committee is determined to fulfil four major functions which make an important contribution towards sustainable development goals (SDGs), especially SDGs no. 6 (clean water), no. 7 (clean energy), no. 13 (climate action) and no. 15 (life on land). The four key functions being undertaken by GBG are as follows:
(1) plant species conservation through research (with a focus on endemic, indigenous, threatened and economically important plants)

(2) conservation of the landscape (control of water and soil erosion as the area is highly rugged and vulnerable to soil erosion)

(3) practical environmental education (from primary to university level)

(4) nature-based ecotourism for domestic and international tourists

These functions particularly support SDG no. 15 , which is mainly concerned with halting degradation by preserving forest, desert and mountain ecosystems.

Since it was founded, GBG has developed its infrastructure in line with its vision and mission. These developments include site clearing and preparation; constructing environmentally friendly buildings, a dam and soil-conservation structures; establishing wetlands; and developing a nursery. Vegetation assessments have been carried out which have led to seed collection, propagation and cultivation as well as the creation of a number of smaller gardens and plantings. In addition, practical environmental education is being delivered to students of all ages and to other communities. The garden is highly suited to sports activities and is very popular with hikers, walkers and joggers.

\section{Selecting a site}

Various sites were identified by a number of stakeholders and institutions as potential candidates for a botanic garden in Addis Ababa. The current site was preferred due to the fact that it already had relatively high plant diversity and a dense canopy, as well as a considerable elevational difference (2,540-3,000 $\mathrm{m}$ asl). A number of other 
factors also made it suitable: proximity to the city centre, two perennial rivers running through it and good accessibility for visitors. The significant variations in altitude and type of landscape mean that a great variety of plants and wildlife already occur there, with scope for cultivating and encouraging more. Being so near to the city allows ecotourism opportunities to be fully realised.

Geographically, the area belongs to the central plateau of Ethiopia with coordinates extending between latitudes of $8055^{\prime} \mathrm{N}$ and $9005^{\prime} \mathrm{N}$ and longitudes of $38005^{\prime} \mathrm{E}$ and $39005^{\prime} \mathrm{E}$. The garden is located in the north-west of Addis Ababa, $4 \mathrm{~km}$ from the centre (Fig. 1). The topography ranges from very steep to moderately steep slopes. The average annual rainfall is between 1,100 and $1,300 \mathrm{~mm}$ and the annual temperature ranges from 15 to $18^{\circ} \mathrm{C}$. February is the hottest month $\left(20.7^{\circ} \mathrm{C}\right)$ and December the coldest $\left(7.5^{\circ} \mathrm{C}\right) . \mathrm{GBG}$, with its location in the mountainous outskirts of the city, forms a main part of the green lung of Addis Ababa where various collections of plants from different parts of the country are found. The garden is sited on Mount Entoto, which is made up of basalts that are covered in volcanic, predominantly clay top soil materials 1-2 $m$ thick. The mountain has very steep, soil-free slopes and cliffs on the northern side and much longer, shallower slopes on the south-eastern side (Haileselassie \& Getaneh, 1989). Historically, the landscape of GBG was dominated naturally by Juniperus procera and by plantations of Eucalyptus globulus introduced in 1895 for fuel wood and silviculture.

\section{Gullele Botanic Garden today} Vision and mission

The vision of GBG is to be a model botanic garden demonstrating the rich plant diversity of Ethiopia, to engage in ecosystem and species-based research, and to deliver education and ecotourism to an international standard. There are five different uses of the land in the garden.

(1) Interface with the city in the zone along the southern edge

(2) Infrastructure, where buildings and facilities for staff and visitors are located

(3) The Artificial Garden, a cultivated garden where greening and thematic gardens are located for amenity education, research and ecotourism

(4) The Scenic Garden, a forested area of the garden where conservation activities (tree planting, natural regeneration and restoration) take place

(5) A nature reserve forest, a largely undisturbed area used less for tourism and more for research

The garden has been accredited by Botanic Gardens Conservation International (BGCl) until 2025. This accreditation is a measure of the degree to which GBG meets the high standards required to be an effective botanic garden, and the intention is to maintain these standards beyond 2025 .

GBG's mission is to provide natural ecotourism services through the conservation of and research into plant species, and to support nature-based science education.

\section{Values}

GBG's values are stated in the GBG Strategic Plan 2016-2020 (GBG, 2015) and are as follows:

- to give priority to research, conservation, and care of species and landscapes

- to appreciate nature

- to contribute to the development of ecotourism in the region 


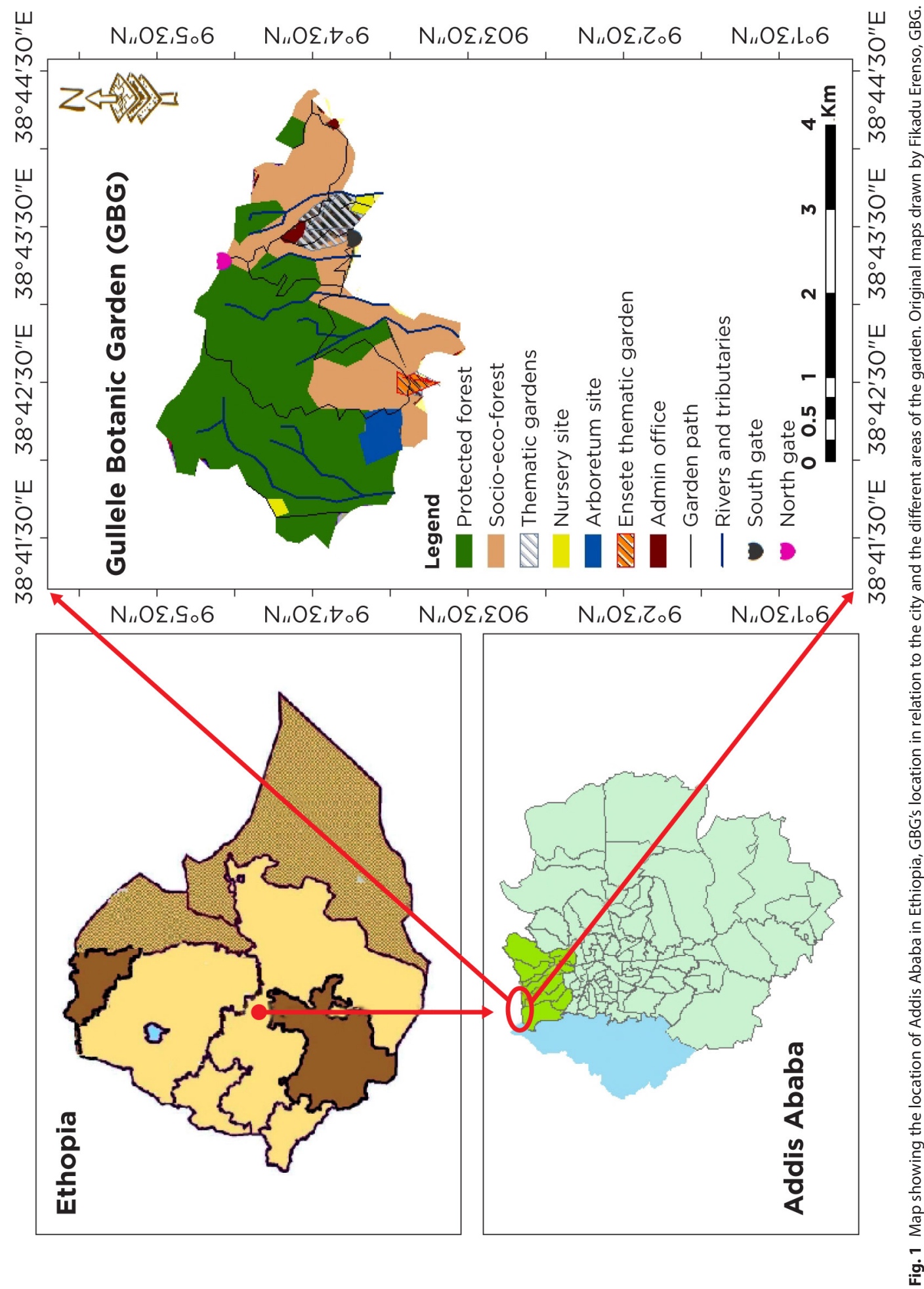


- to provide practical science education

- to carry out community development activities

\section{Infrastructure development}

Many infrastructure projects have been realised since GBG was established (Fig. 2).

These include a $21 \mathrm{~km}$ access road, parking for up to 150 vehicles inside the garden and 300 outside, a watchtower, toilets, fences, a mini- greenhouse, an eco-friendly building (Agora II), two main entrance gates, a weather station and a borehole to supply water. In 2020, construction got under way of an administrative and research building, a plant sales area and a reception building. Future intentions include plans to construct a suspension bridge, a cable car and an amphitheatre.

\section{Research activities and collection management}

GBG maintains plant species in danger of extinction, particularly endemic, native and economically important plants, and research outcomes are applied to assist in local and regional sustainable development (Ergua et al., 2020; Woldegerima et al., 2017). Research on species interaction, ecological dynamics and vegetation-climate change relations are core functions of the garden.

The starting point of these activities was a floristic assessment of the landscape. A total of 223 plant species belonging to 66 families and 163 genera were recorded (Birhanu, 2009) before the garden opened. More than 10 per cent of the garden flora composition is endemic to Ethiopia. Some of the plant species recorded are locally and internationally threatened according to IUCN Red List criteria, and assessment is in progress at the time of writing.

GBG is dedicated to curtailing the destruction and eventual extinction of plant diversity through in situ and ex situ conservation techniques, and has therefore sought to increase the plant diversity in the garden. This has been done through the development of a thematic garden and a wetland and evolution garden, and with the collection of plants and seed from different parts of the country. The establishment of these species has been improved through acclimatisation in the greenhouse and the use of propagation facilities.

The number of plant species in the garden has increased in recent years to over 1,200 , through collection and improved in situ management techniques. Of the new accessions collected, 166 are medicinal plants. Sixty-five of these were found to be endemic to Ethiopia and Eritrea (Appendix I) according to Flora of Ethiopia and Eritrea (Hedberg et al., 2009). The 65 endemic plants include trees, shrubs, succulents, herbs, one parasitic species, one climber and one liana. In addition, a significant number of herbarium specimens, seeds and parts of plants for propagation have been collected from all parts of the country.

The collection of live plants, seeds and herbarium specimens is a fundamental activity. GBG has been collecting seed and vegetative plant material using the scientific method described by Hawthorne \& Marshall (2016). Information on the geography, agro-ecology and environment are all noted, along with data on the habit and morphological features of the plants. A project carried out in collaboration with $\mathrm{BGCl}$ called 'Verify the Biological Importance of the Sof Omar KBA' (Shaw, 2017) is considered an exemplary study and demonstrates the value of research activity at GBG. Once collections have been made, sowing and planting follow in collaboration with the garden's horticultural departments. Propagation 

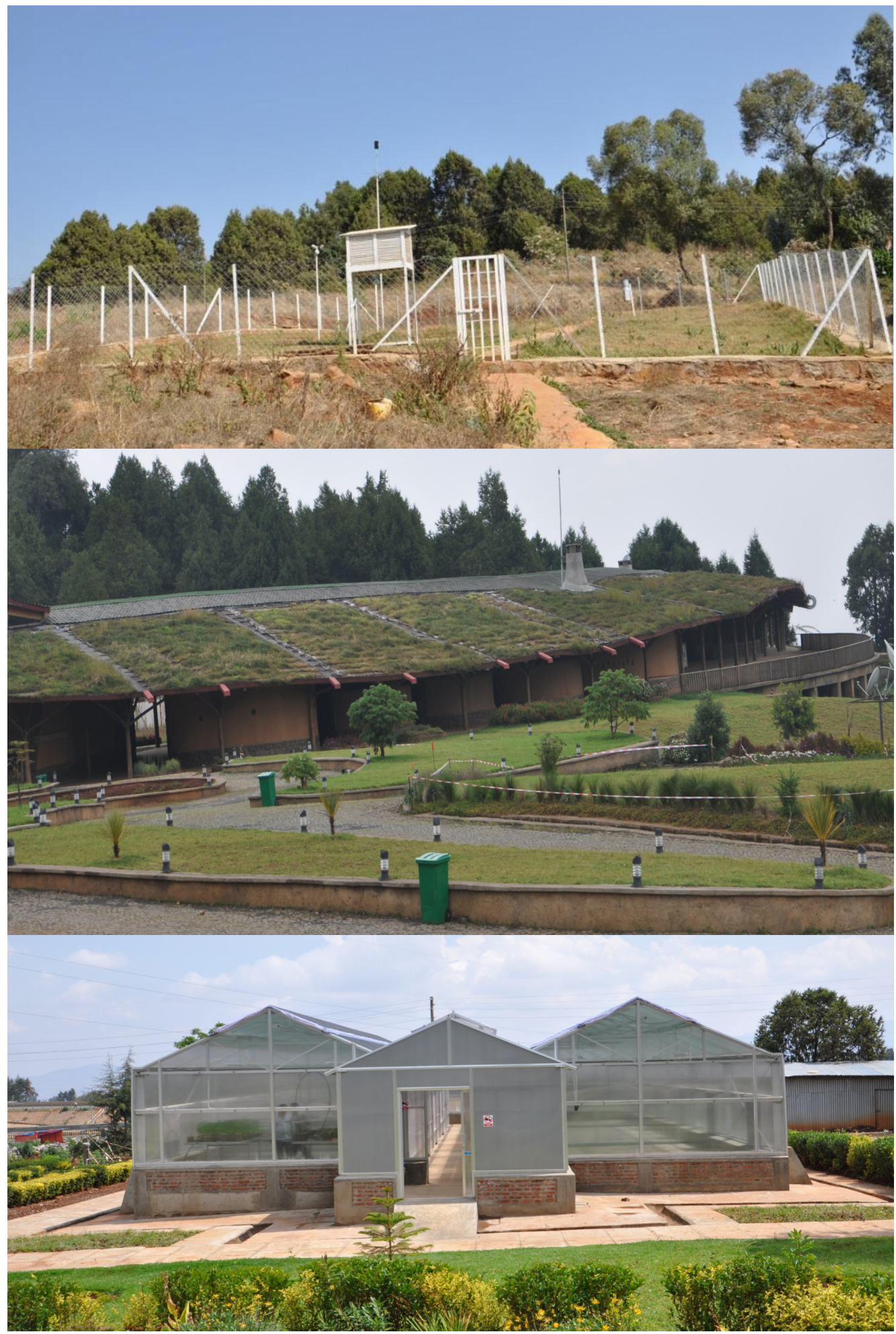

Fig. 2 Examples of new infrastructure: (top) weather station (centre) research facility buildings (bottom) greenhouse. Photos: Communication unit, GBG. 
and planting, reforestation, and natural regeneration of indigenous and endemic plants have all contributed to GBG's increased flora (Fig. 3).

GBG provides a green lung for Addis Ababa, with ecosystem services such as carbon storage, habitat support and protection from soil erosion. The garden has an estimated average carbon density of 156 tonnes/ha (Woldegerima et al., 2017). The highest carbon density of 265.8 tonnes/ha was recorded in the dense forest around GBG. The dominant tree species, Eucalyptus globulus and Juniperus procera, have a carbon density of 233.1 tonnes/ha and 87.8 tonnes/ha respectively (Woldegerima et al., 2017). This research has only considered the natural vegetation and eucalyptus species planted several decades ago and has not studied the cultivated portion of the garden. If the latter had been included, the overall carbon density would be greater.

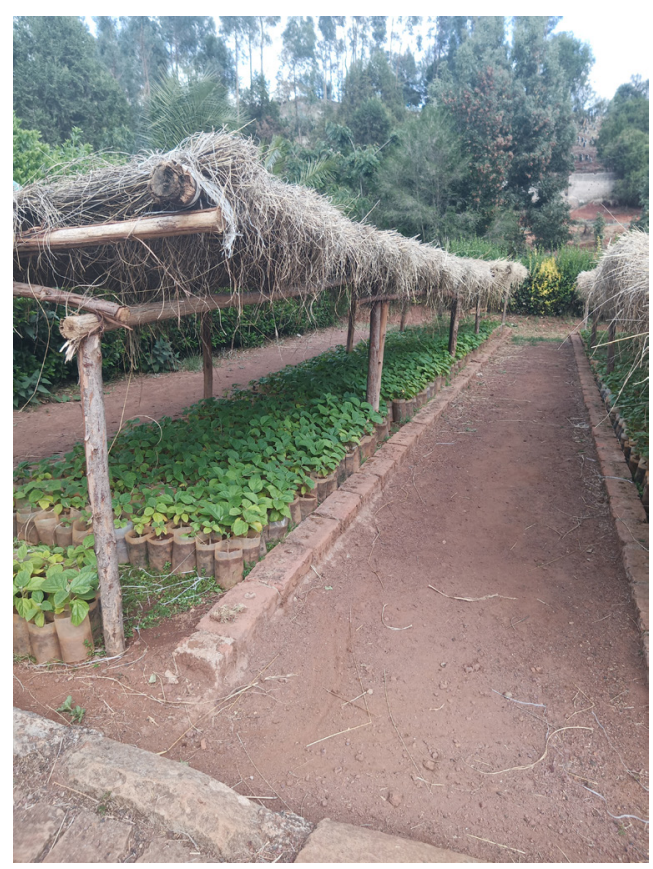

Fig. 3 The indigenous Cordia africana, propagated from seed. Photo: Talemos Seta.
GBG currently contributes to climate change mitigation in and around the city, which is attributed to the cooling effect and water-holding capacity of the dense Juniperus-dominated forest, and the soil and water erosion protection which has been installed.

Besides many development activities, a number of research projects are being conducted at GBG. These include studies on pollination biology, ecosystem services, ecotourism, propagation techniques, phenology, and the selection of indigenous and endemic species suitable for ornamental displays. Accreditation by $\mathrm{BGCl}$ in 2018 has ensured that GBG is recognised at an international level, which has created a suitable environment for collaboration and knowledge exchange with other institutions. Professor Sebsebe Demissew, Executive Director of GBG in 2018 and now Professor of Plant Systematics and Biodiversity Conservation at Addis Ababa University, played a central role in the accreditation process. As a consequence of this international recognition a number of smalland medium-level grants have been awarded for programmes in conservation, collection and propagation, nursery expansion, outreach services and training. Organisations that have supported these projects include $\mathrm{BGCl}$, the Mohammed Zein Foundation, the Horn of Africa Regional Environment Centre and Network, World Agroforestry (ICRAF) and One Tree Planted Inc.

$\mathrm{BGCl}$ and the University of Oxford Botanic Garden and Arboretum collaborated with GBG on a project to survey and collect propagation material from threatened tree species across Ethiopia. The focus areas for survey and collection were Sof-Omar, a cave system in south-eastern Ethiopia, and Harar, a walled city in the east of the country. The 
project was extended to include the survey and collection of propagation material of two Critically Endangered species Boswellia ogadensis (B1ab (iii)) and Euphorbia burgeri (B1ab (iii,v)) - and five Data Deficient species - Commiphora ogadensis, Erythrina burana, Moringa ruspoliana, Terminalia basilei and T. hararensis, all from the Harar region.

\section{Wildlife in the garden}

As well as being a centre for plant conservation, GBG has many wildlife resources, with 11 large mammals (Appendix II) and 95 bird species recorded (Fekadu et al., 2011). Tragelaphus scriptus meneliki (Menelik's bushbuck) is an endemic subspecies considered to be a montane form of the spiral horned antelope of Africa, which occupies a limited and disjunct range in mountainous Ethiopian forest.

Of the bird species in the garden, 13 are expected to be endemic to Ethiopia and Eritrea, although further research is required to confirm this figure (Appendix III). It is understood that plant species assemblages increase those of bird species in forest and garden ecosystems and therefore as the plant diversity in the garden continues to increase with future garden developments, it is expected that the bird list will grow too.

\section{Research facilities}

One of the requirements of a botanic garden is the presence of a herbarium to deposit dried plant specimens. In our case, a herbarium is important for providing a foundation for training in plant diversity, running educational courses for interested members of the public and exposing students to the discipline of plant systematics. The mini-herbarium at GBG contains five cupboards with two boxes each, a deep freeze, a drier, and plant-collection and pressing equipment. The herbarium was extended in 2020 to include one more room with movable cupboards. Specimens brought to the herbarium through collections are organised according to Flora of Ethiopia and Eritrea (Hedberg et al., 2009), similar to the classification system of Ethiopia's National Herbarium (ETH). The organisation follows the classification of families into genera and then species for each plant specimen. Thus, all the plants belonging to one plant family have been placed in adjacent cupboards. Each plant family is represented by numbers $1,2,3 \ldots$ up to 215 in the cupboards so that new collections will be included. The plant specimens should be identified at species level to be organised in this mini-herbarium. Currently, over 1,000 plant specimens have been identified and deposited there. Otherwise, unidentified specimens are stored separately, awaiting review and identification by experts.

As well as the mini-herbarium, the botanic garden has a mini-laboratory for conducting research activities which do not require expensive chemicals and laboratory equipment. Some of the facilities in the mini-lab include a growth chamber, washing facilities, flasks, beakers and other smaller instruments for germination testing. A new building called Agora I (under construction in 2021) will have laboratory facilities for conducting more advanced biological investigations into physiological, molecular, biotechnological, plant systematics and genetic level research, in addition to simple germination and propagation research.

\section{The living collections}

\section{Nursery}

The nursery site, where seedling production and propagation take place, has one 
miniature greenhouse for the acclimatisation of a range of plant species. The nursery site has been recently extended to 4 ha to allow up to 1 million seedlings to be produced as part of the tree-planting programme to serve the surrounding communities. It is planned that the construction of a $10,000 \mathrm{~m}^{2}$ greenhouse will allow greater control over the growing environment of different types of plants, including indigenous plant seedlings (Fig. 3).

\section{Thematic garden}

GBG contains themed cultivated sections, occupying 5 ha in total, based on the plants' uses, historical backgrounds and evolutionary relationships. The plantings are stocked from the nursery. A new theme, 'IUCN Red List', covering 1 ha, was recently added to this area. A cluster of themes are situated on the south-western side of the cultivated garden, close to the entrance to the Agora building, where visitors start their tour. It is a strategic location, enabling visitors who are more interested in the collections concentrated and displayed here than in walking through the whole garden to access them easily. The thematic garden includes a medicinal garden, an endemic garden, an ornamental garden (Fig. 4), an evolution garden, a wetland garden, a garden displaying the family Asteraceae and another displaying the family Poaceae, a fragrant garden, a rock garden, a wild edible garden and a succulent garden (Fig. 5), with others in development.

Two of the most important thematic gardens are the medicinal garden and the evolution garden; these are described in more detail below.

\section{Medicinal garden}

This area contains plants of medicinal importance which are locally at risk due

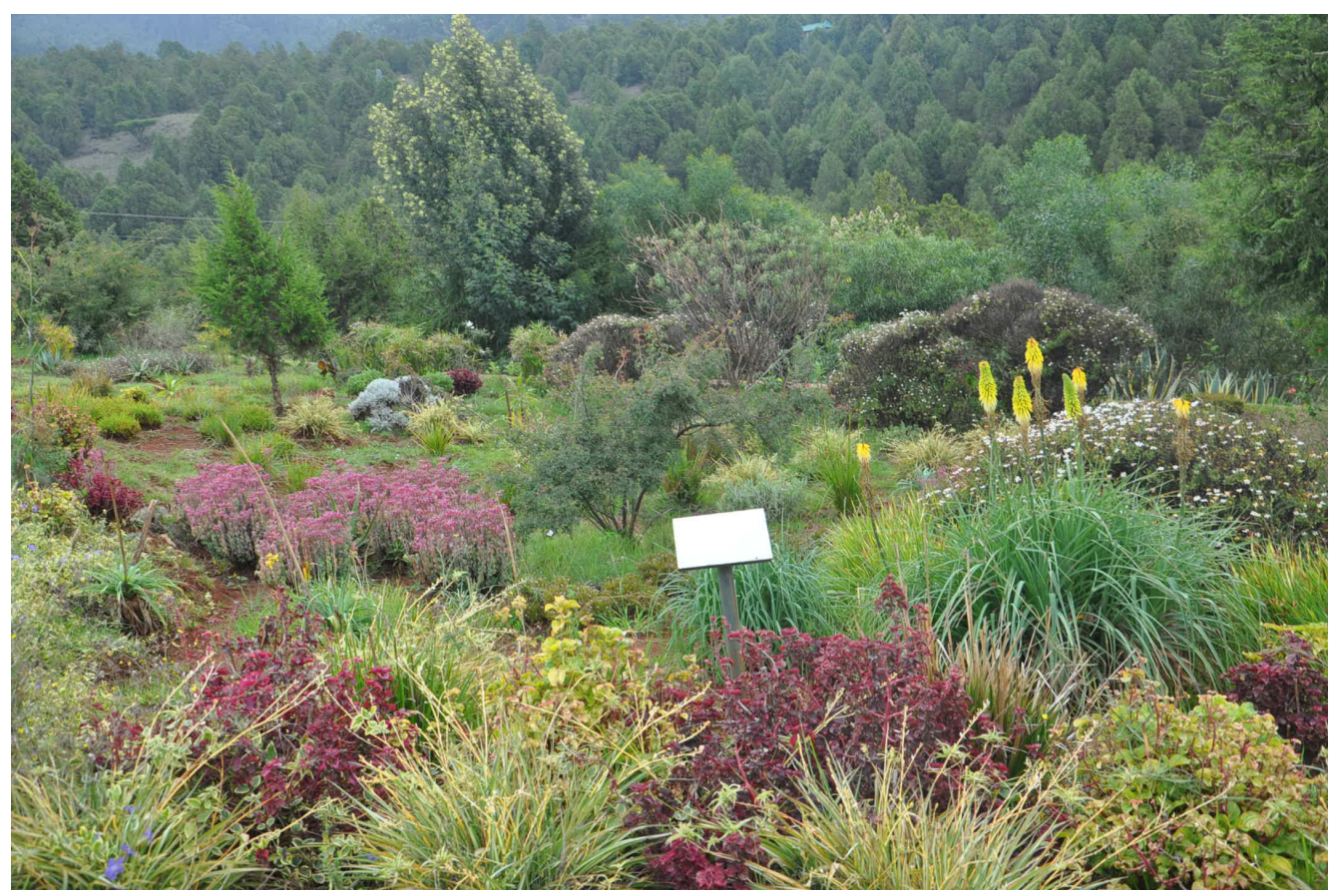

Fig. 4 The ornamental garden. Photo: Communication unit, GBG. 


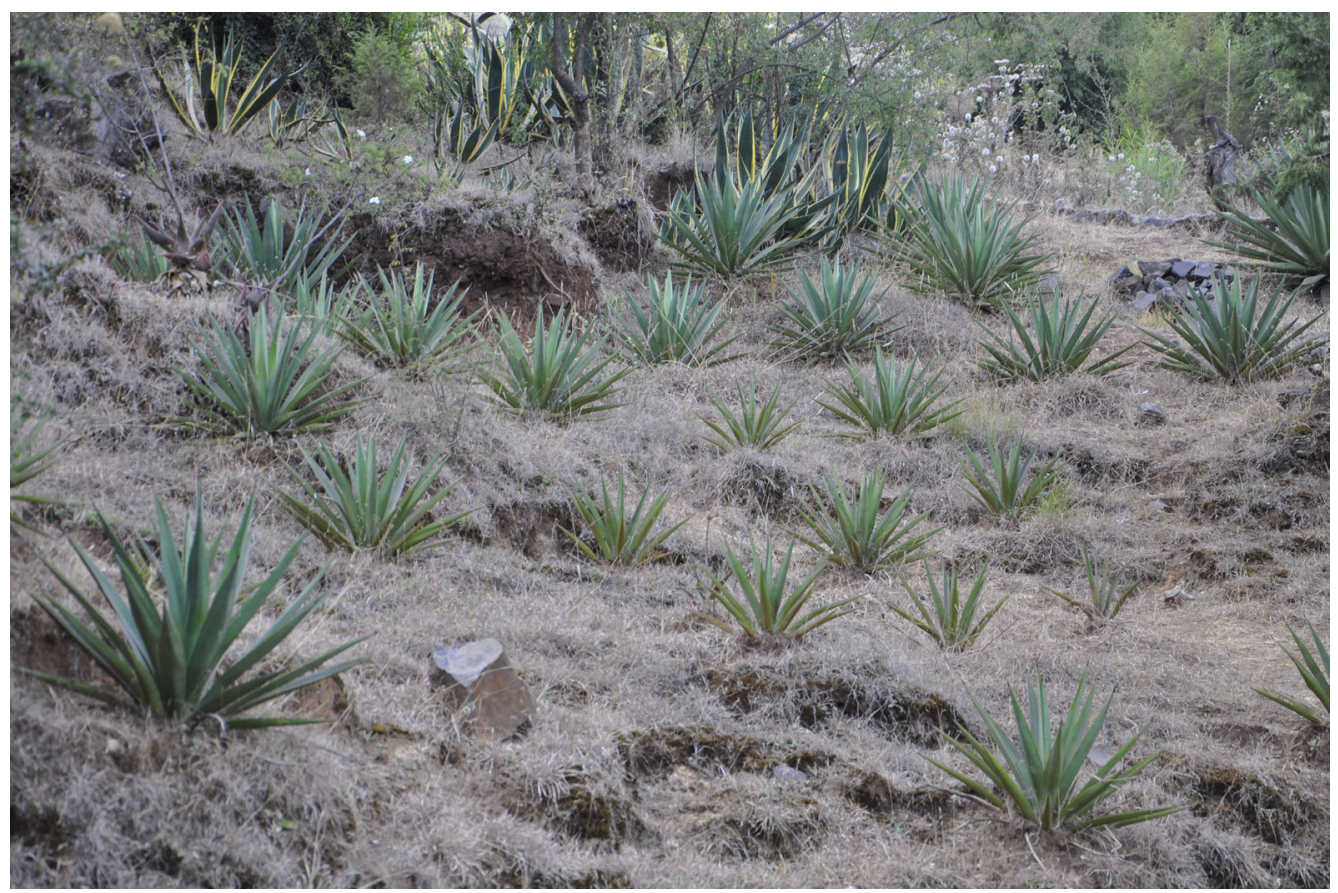

Fig. 5 The succulent garden. Photo: Communication unit, GBG.

to widespread use and overharvesting. In Ethiopia, the indigenous people of different regions have traditional knowledge based on their particular cultures and lifestyles. The area has therefore been developed for both display and conservation purposes and also illustrates the relationship between plant diversity, culture and traditional knowledge. A single plant can have a number of medicinal values for many different ailments. A total of 166 medicinal plants are cultivated in this area and occur naturally in the forest section of the garden. The medicinal plant collection is useful for conservation of the species displayed here, and helps to address the loss of traditional knowledge and the unsustainable use of natural resources. Traditional healers around Addis Ababa are working in close collaboration with GBG to source plant material for their use.

\section{Evolution garden}

This area has been established to show the evolution of plant life (Fig. 6). It contains life forms starting from liverworts to flowering plants. Its main purpose is educational and it is used as a teaching garden. The arrangement of flowering plants in the evolution garden follows the APG (Angiosperm Phylogeny Group) classification system in the botanic garden. The APG system is based mainly on the circumscriptions of families, orders and higher-level clades within the angiosperms. The system has undergone three revisions, with the most recent (APG IV) published in 2016 (APG IV, 2016).

\section{Ornamental horticulture}

GBG has a horticulture department responsible for the greening and beautification of the infrastructure and cultivated sections of the garden. An area covering around 14.5 ha 


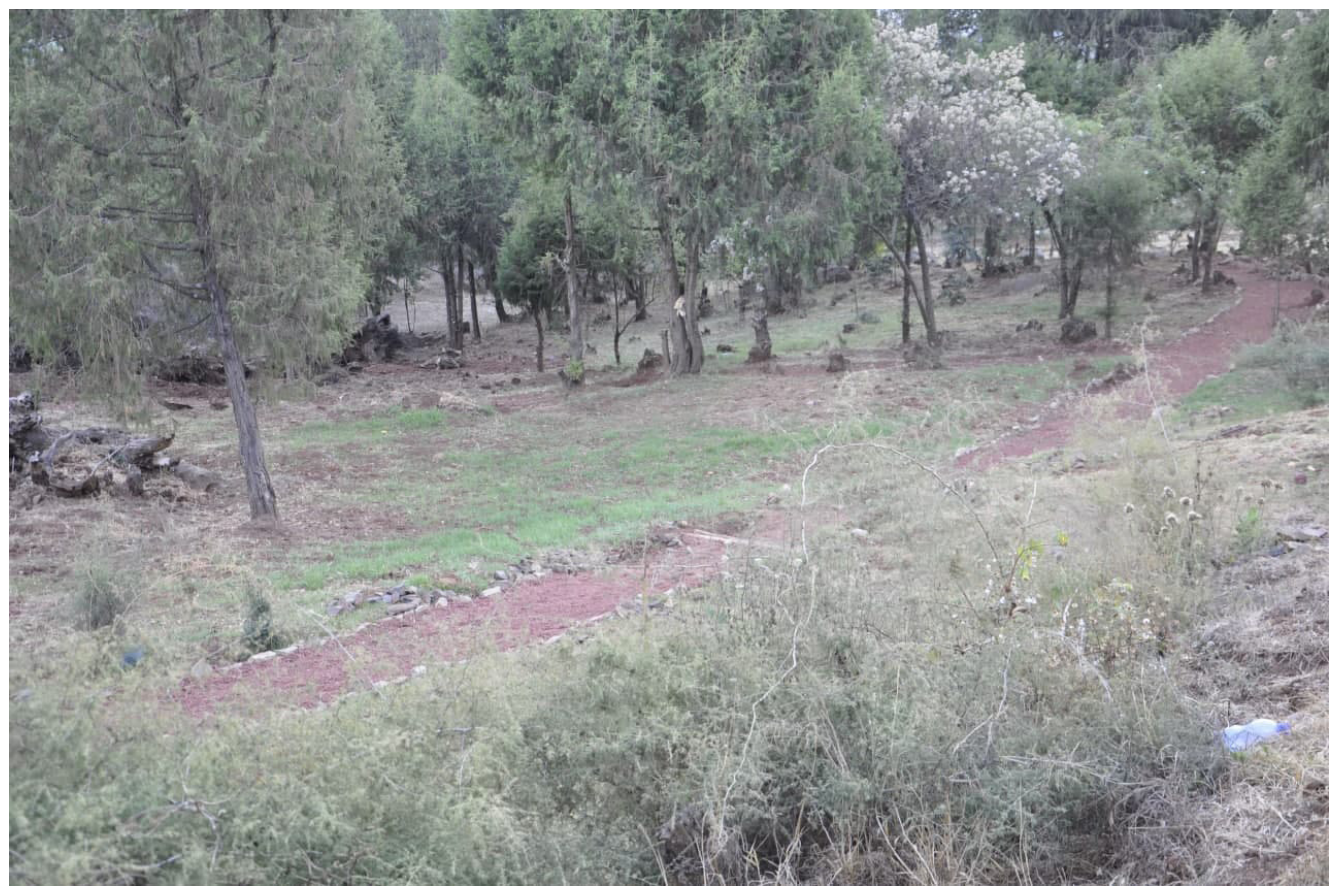

Fig. 6 Juniperus procera represents gymnosperms in the evolution garden. Photo: Communication unit, GBG.

of lawns and green areas has been established (Fig. 7). Indigenous and/or endemic trees and non-native ornamental species have been planted along the main road and walkways to increase plant diversity, with these plantings providing ornamental value as well as shade. These attractive areas are enjoyed by tourists and serve as locations for a variety of events that take place at weekends. Such ornamental areas are important for GBG as they bring together the promotion of beautiful outdoor spaces and the garden's science, education and research purposes, making them accessible to the public. The continual support given by horticulture to taxonomic research is of significant value in botanic gardens in general and GBG in particular. In addition, the horticultural collections are a resource for study in themselves. These collections provide material for research into cultivated plants until they flower and/or set seed, flower initiation, trials, the cultivation of plants that are difficult to press, such as orchids or succulents, and the growing of a wide range of plants to a high standard as aids to taxonomic description.

Another resource is a unique arboretum that covers 1 ha and contains endemic and indigenous trees and shrubs for display, conservation and education purposes. The arboretum was established in 2019 and at the time of writing the seedlings are in good health thanks to ongoing care and management. A fruit garden of 2 ha has been established to conserve highland fruits, such as different varieties of apple, and to provide practical education and ecotourism services.

\section{Soil and water conservation activities}

GBG is part of the Entoto mountain chain which has been predominantly covered 


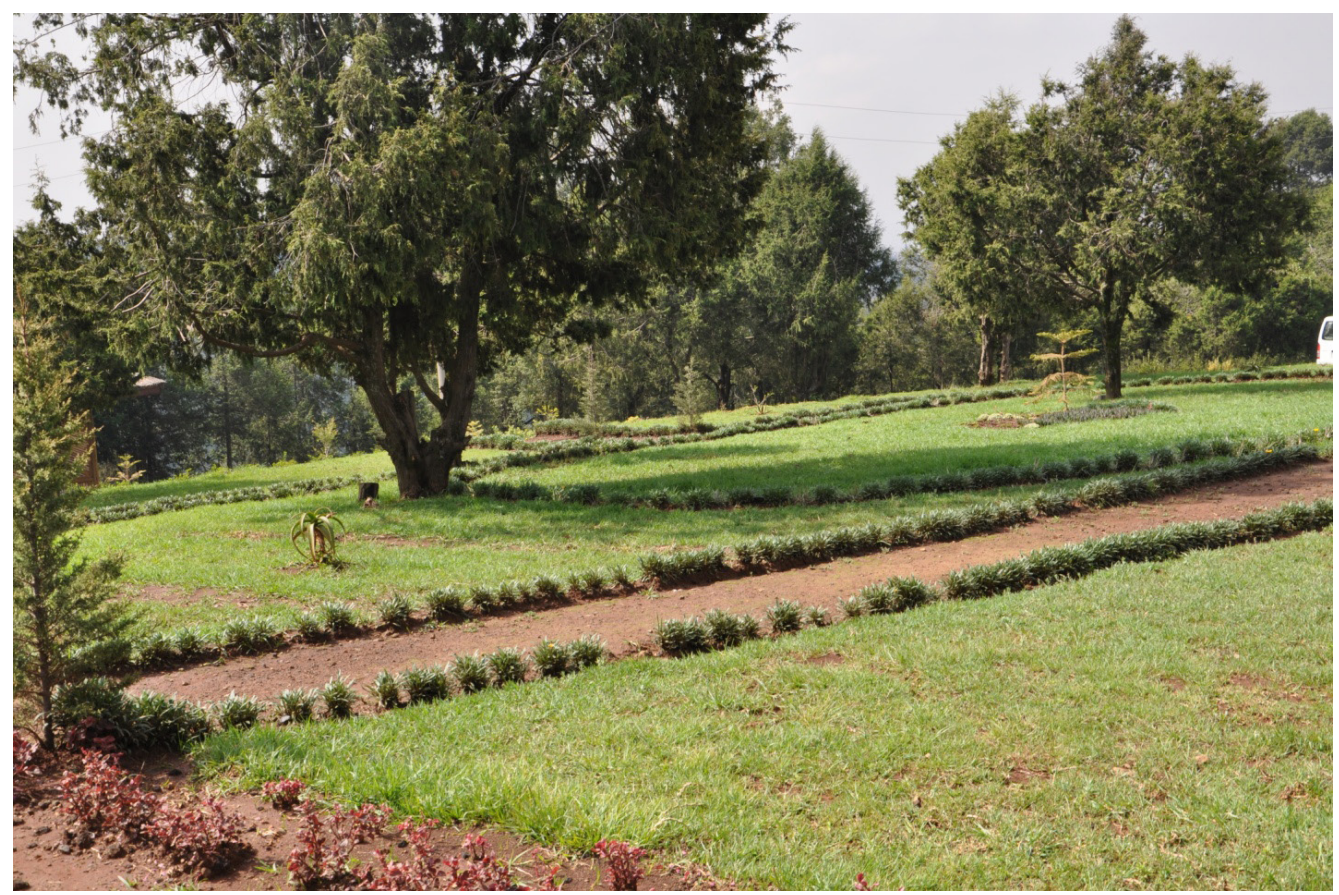

Fig. 7 Lawn making and beautification in the botanic garden. Photo: Communication unit, GBG.

by Eucalyptus globulus since the early 19th century. Mount Entoto largely has an undulating topography with steep slopes highly prone to severe runoff, causing soil erosion. From the early days of the garden, soil and water conservation measures have been implemented using two main methods:

(1) biological - planting grasses; and

(2) physical - building structures that include terraces made of stone, wood and soil;

Gabion check dams made of stone and wood; trenches that form water infiltration ditches; cutoff drains which are canals to divert runoff; and wire mesh (Fig. 8).

Table 1 shows the different soil and water conservation structures created in the highly depleted and affected parts of GBG since 2010.

\section{Eucalyptus replacement}

Eucalyptus globulus was introduced to

Ethiopia and specifically to this site in 1895 in response to a critical wood shortage in the rapidly expanding capital, Addis Ababa. However, later research showed that eucalyptus depletes the nutrients and moisture reserves of the soil and inhibits the growth of understorey species due to its allelopathic properties. Besides, the dead plant parts decompose very slowly, adversely affecting nutrient cycling. It was agreed that the area covered by this species - 70 per cent of the GBG site - should be replaced with indigenous species, either by planting new seedlings or by allowing natural regeneration. This meant that removal of the eucalyptus was a mandatory activity. The trees were duly harvested to generate finance for the garden. Once a specific area of eucalyptus has been harvested, the coppices must be debarked immediately to inhibit fast regrowth (Fig. 9). Debarking must continue each year for four or five years to ensure that the trunk is completely dead. 


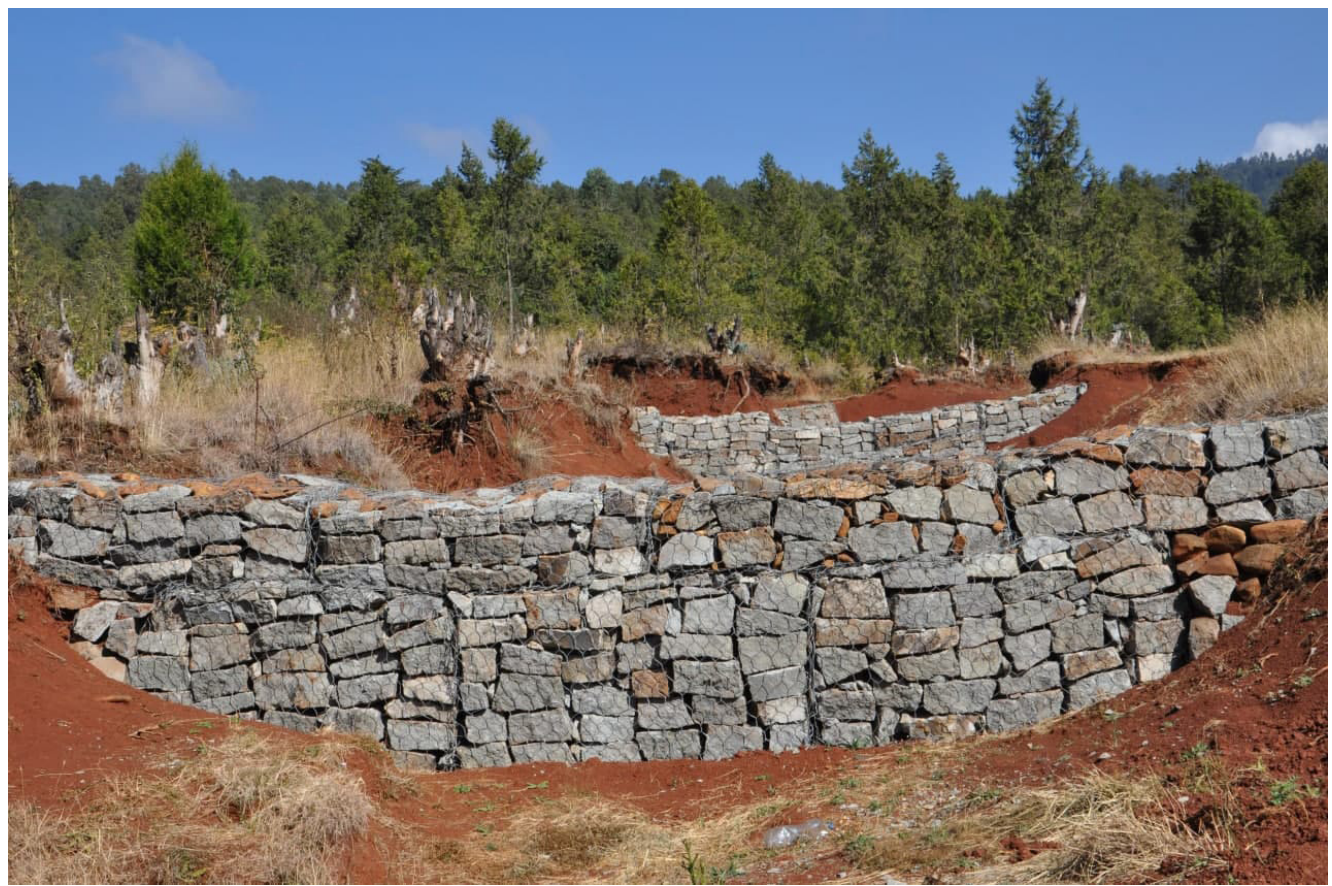

Fig. 8 Gabion check dam (strong enough to resist the force of runoff). Photo: Communication unit, GBG.

Table 1 Soil and water conservation measures implemented since 2010.

\begin{tabular}{|l|l|l|}
\hline \multicolumn{1}{|c|}{ Activity } & \multicolumn{1}{c|}{ Unit } & \multicolumn{1}{c|}{ Quantity } \\
\hline $\begin{array}{l}\text { Soil erosion protection (cutoff drains, hillside terraces, stone-faced } \\
\text { soil bands) }\end{array}$ & $\mathrm{m}^{2}$ & 4,854 \\
\hline Wiremesh/Gabion check dams & $\mathrm{m}^{2}$ & 1,250 \\
\hline Stone and wood check dams & $\mathrm{m}^{2}$ & 2,700 \\
\hline Deep trench and retaining wall & $\mathrm{m}$ & 5,130 \\
\hline Micro basin/half moon & $\mathrm{m}^{2}$ & 1,210 \\
\hline Swamp area development & $\mathrm{no}$. & 5 \\
\hline Biological method (planting trees) & $\mathrm{m}$ & 4,700 \\
\hline
\end{tabular}

Around 561 ha have recently been freed of eucalyptus trees and replaced with Juniperus procera mixed with Rosa abyssinica, Olinia rochetiana and other indigenous species. In order to rehabilitate the former plantation area, over 95,000 seedlings of different species have been planted and fences have been constructed to exclude the area from disturbance in order to enable natural regeneration.

\section{Environmental education and outreach}

Botanic gardens can be inspirational outdoor classrooms for all ages from early years to higher education. GBG provides 


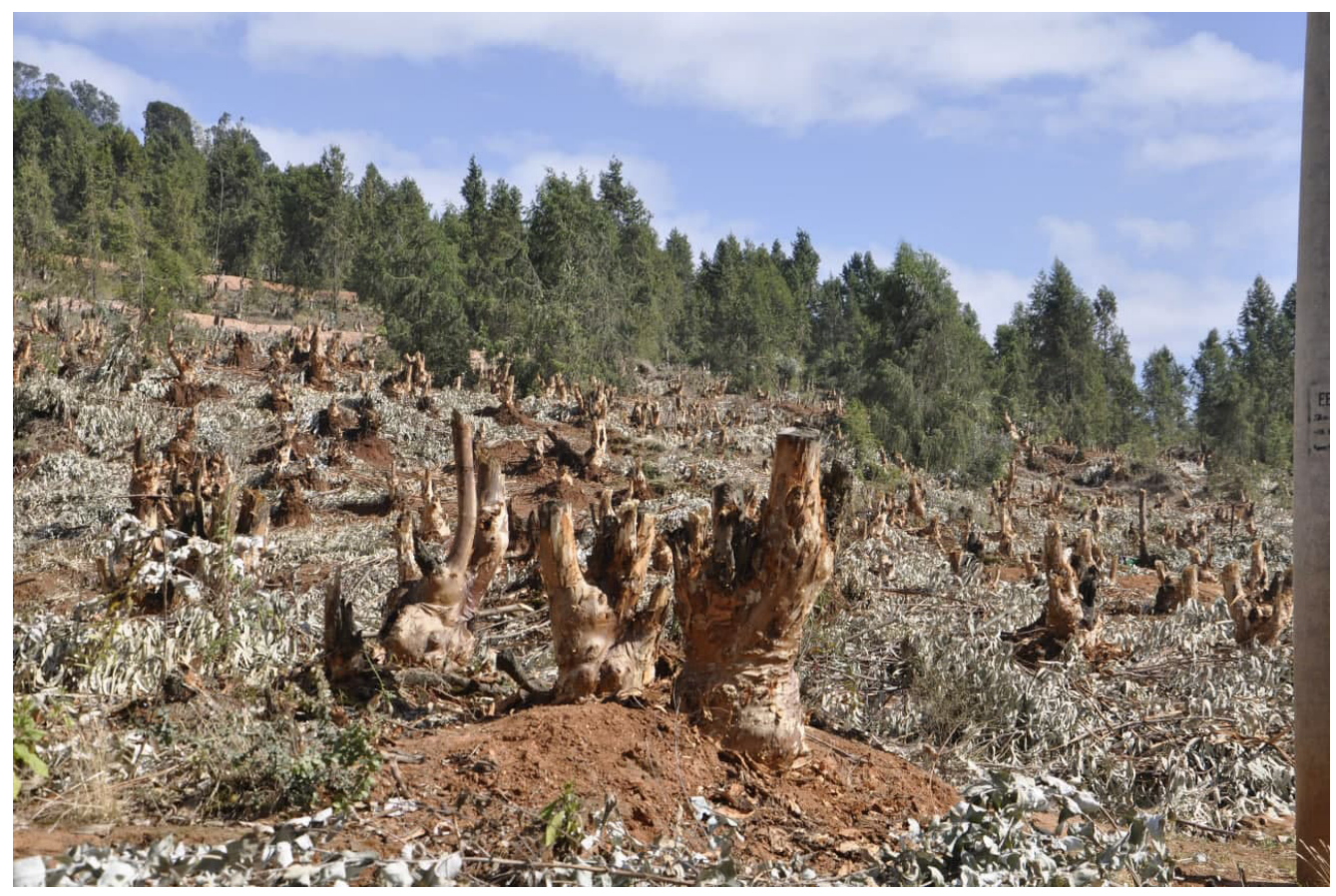

Fig. 9 The first stage of eucalyptus debarking. Photo: Communication unit, GBG.

environmental education services for students at all levels as well as other stakeholders. The environmental education department is responsible for planning, capacity building and training, education and outreach services related to gardening, greening and practical science education for the betterment and sustainability of the environment we live in (Fig. 10).

GBG has provided practical environmental education and awareness creation services for around 138,500 customers of different groups since service provision began in 2012 (Fig. 11). As an outreach programme, model gardens have been set up in ten schools in the city of Addis Ababa. Similarly, two community gardens have been established. The schools and communities are responsible for the care and management of their gardens, with consultative support provided by GBG staff. Practical training as internships for students and gardeners has also been provided to smaller numbers because this training requires more intensive small group work over a longer period (Fig. 12).

\section{Ecotourism services}

GBG has been providing nature-based tourism services for urban and peri-urban communities since the garden was founded in 2010. The opportunity to visit a natural or near-natural setting in the botanic garden is very important for many urban communities in the city. Some of the ecotourism opportunities provided by the garden include trekking, forest and canopy walks, jogging, mountain biking, picnic areas, night camping, a panoramic view of Addis Ababa, birding, social events such as weddings, festivals and birthday celebrations, opportunities for filming and photography, sports and yoga, and cafeteria services.

One such event was a children's festival of 


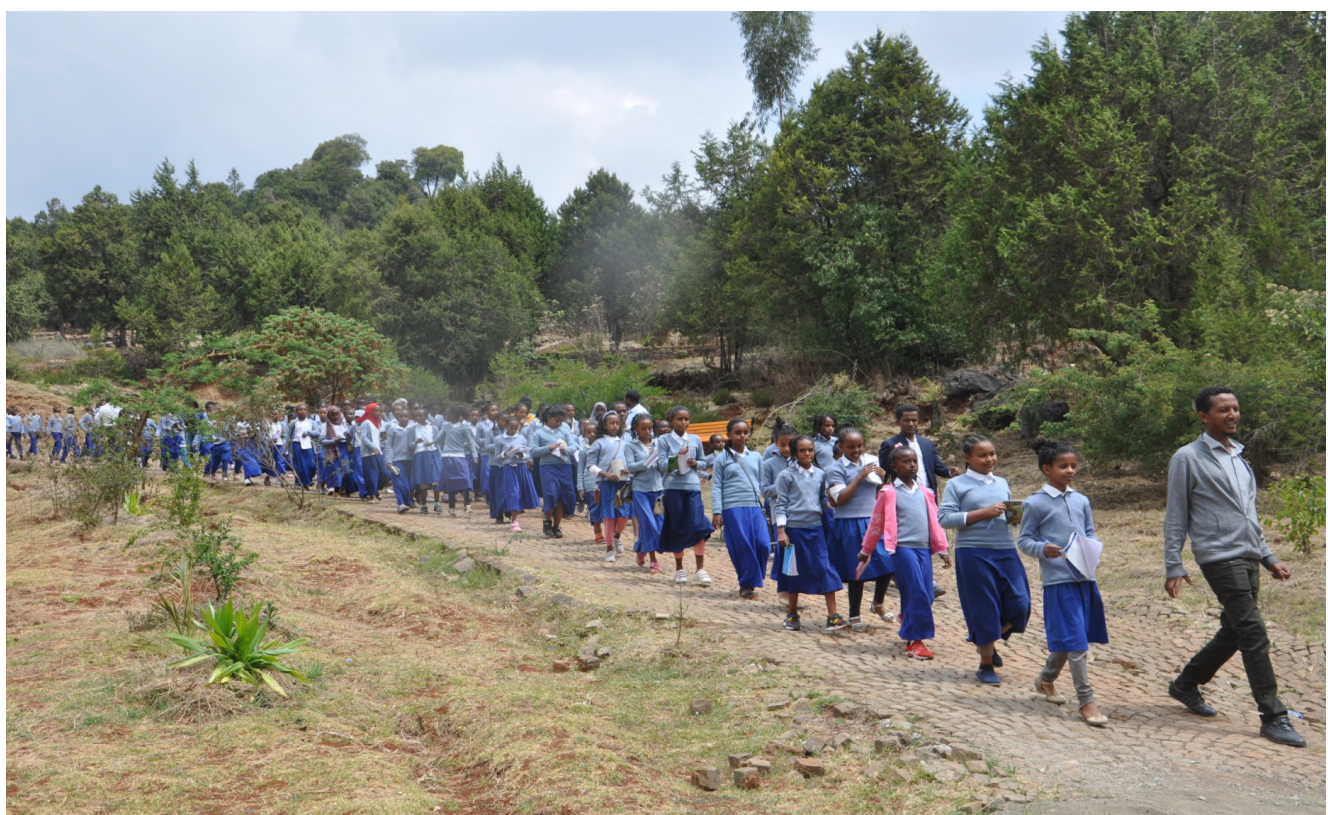

Fig. 10 Education service for primary-level students. Photo: Communication unit, GBG.

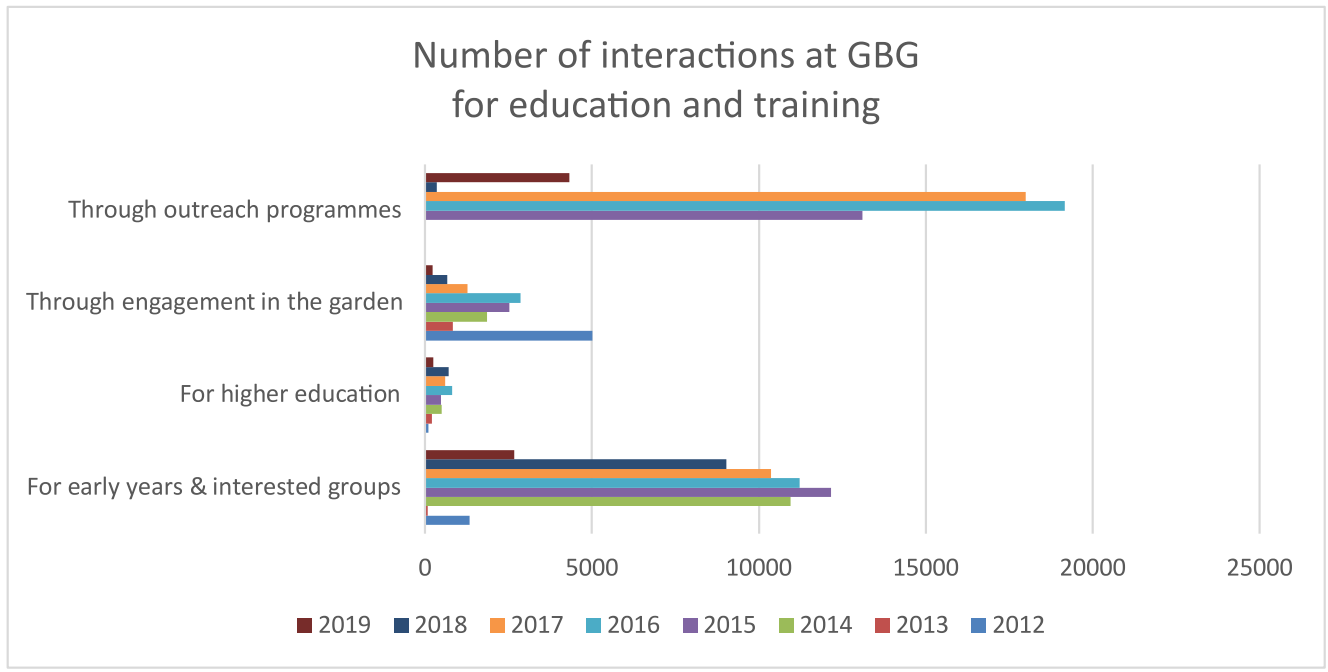

Fig. 11 Number of interactions with individuals including schoolchildren and adults 2012-2019. The years 2016 and 2017 were particularly busy ones for the education programmes.

sport, organised in 2018 and with over 200 attendees.

The garden has several topographic features which are attractive destinations for tourists, both in the cultivated areas and in the more 'natural' or 'wild' sections of the garden. These include Agora II, Warka Lodge, the plant display, the thematic garden and Dimdim Peak which has a panoramic view of Addis Ababa. The small Warka Lodge has a cafeteria and recreation services. These are open to visitors during the day (Figs 13 \& 14). 


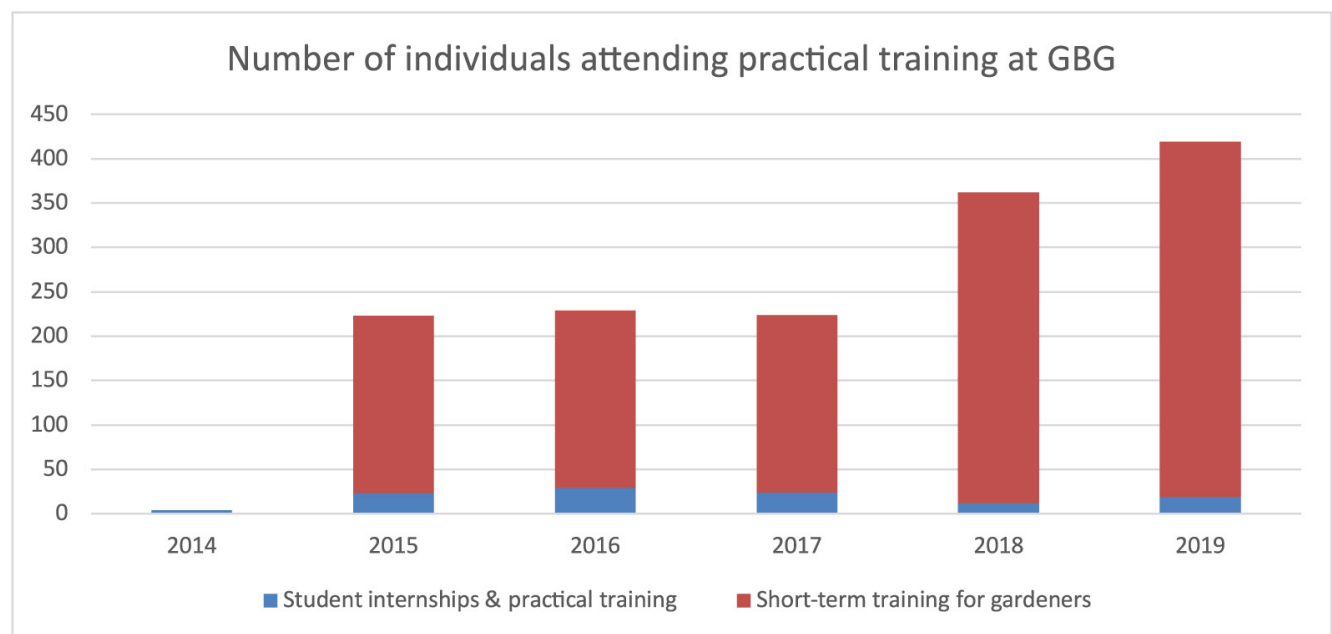

Fig. 12 Number of students and others who attended internships and other practical training opportunities 2014-2019.

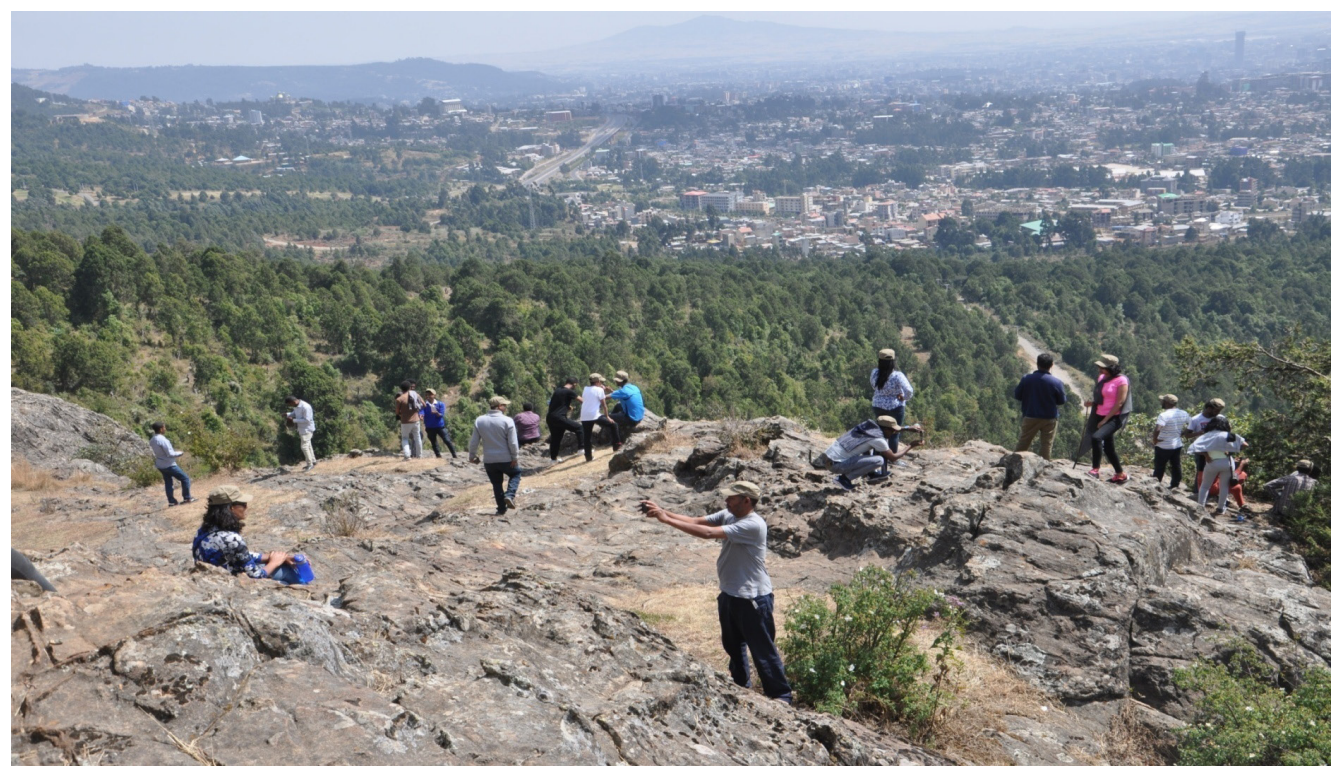

Fig. 13 Dimidim Peak, with its panoramic view of Addis Ababa. Photo: Communication unit, GBG.

Around 200,750 tourists have visited the botanic garden since 2014. The number of visitors from 2014 to 2020 is smaller than expected and indicates that more promotion of the tourist destinations in the botanic garden is required. Moreover, there were fewer visitors in 2020 as the garden was closed for the six months from
March to August because of the Covid-19 pandemic.

It is crucial to follow the principle of sustainable ecotourism within concepts of sustainable development; this is indicated in the GBG Strategic Plan (GBG, 2016-2020). Bramwell \& Lane (1993) outlined four basic principles of sustainable ecotourism: 


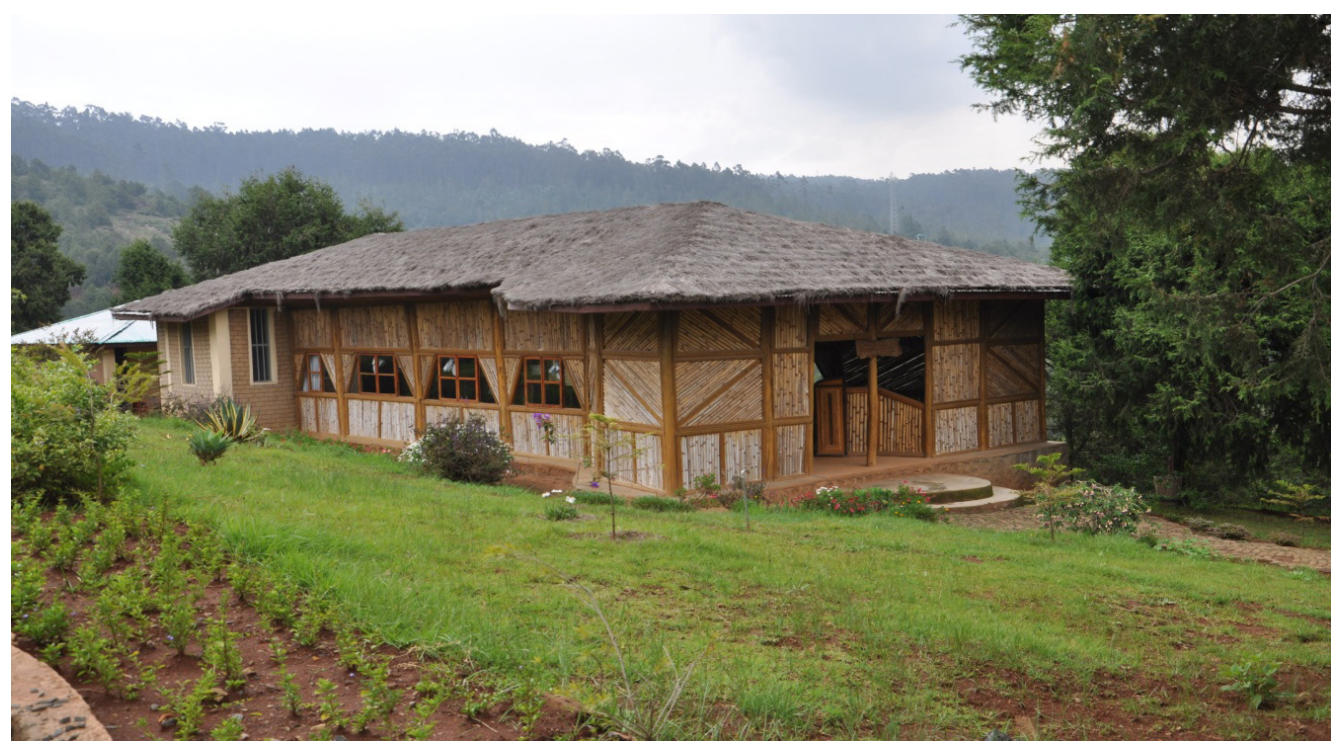

Fig. 14 Warka Lodge. Photo: Communication unit, GBG.

(1) holistic planning and strategy

(2) preservation of essential ecological processes

(3) protection of both human heritage and biodiversity

(4) development to ensure that productivity can be sustained over the long term for future generations

It is fundamental for GBG to take these important concepts into account when planning and implementing developments.

\section{Challenges and opportunities}

The Management Committee of GBG has made every effort to put in place the required facilities and human resources to fulfil its mission and achieve its vision. However, there are many challenges for the short, medium and long term. These include:

- a shortage of water

- a landscape design that has not been adequately developed to freely execute the activities according to the plan
- a lack of practically trained taxonomists for plant identification

- insufficient laboratory facilities and equipment to conduct experimental research

- the lack of a seed bank

- poor public awareness of the role of GBG

- insecure governance structure under organisations not similar in function to a botanic garden

GBG does however have a number of assets which are beneficial to its development:

- The botanic garden covers a large area (705 ha).

- Adequate labour for maintenance is available.

- It has good proximity to Addis Ababa, capital of Ethiopia and diplomatic centre for the African Union and the world.

- There is ample opportunity for collaboration with universities and other similar organisations within Ethiopia and overseas. 
- It received recognition by and official accreditation from BGCl in 2018.

- It enjoys a beautiful landscape suitable for ecotourism.

\section{Plans for the future}

Research, plant conservation and

environmental education activities are all very important. In the next five years it is planned to strengthen GBG's infrastructure to facilitate more ecotourism services and increase income generation. Projects that will contribute to this include solving the water shortage for plant irrigation; building an irrigation network; expanding laboratory facilities and installation; a cable car project; a suspension bridge; an amphitheatre; a children's playground; disabled access; a seed bank and facilities for germplasm storage; a DNA extraction machine; a plant labelling machine; and a conference hall with plant display facilities. GBG is also responsible for assisting the implementation of a planting campaign for the green legacy of the country at city level.

To improve on and increase GBG's capability, the following action points are recommended:

- train technical and non-technical staff in the areas of horticulture, research, plant collection and documentation, and environmental education

- create a strong research culture to demonstrate the importance of ex situ collections

- encourage horticultural staff to get involved in research and education and recognise the value of horticultural practices and procedures

- form networks with botanic gardens at an international level and contribute to training and capacity building at all levels using staff exchange principles
- enable efficient use of water resources to promote horticultural activities

- develop a detailed landscape design in order to establish as many thematic gardens as possible based on the planthuman relationship

- encourage use of the thematic gardens for research and collect relevant data on an ongoing basis for scientific research and analysis

- ensure each theme is well documented and each plant species has a description containing its ecology, biological traits, uses and culture, propagation methods and so on. The documents should either be published or be available for internal reference.

Finally, as an institution GBG is open to communication and collaboration for the development of research and conservation projects with other organisations working on conservation, climate change mitigation and environmental protection.

\section{References}

ANGIOSPERM PHYLOGENY GROUP, CHASE, M.W., CHRISTENHUSZ, M.J.M., FAY, M.F., BYNG, J.W., JUDD, W.S., SOLTIS, D.E., MABBERLEY, D.J., SENNIKOV, A.N., SOLTIS, P.S. \& STEVENS, P.S. (2016). An update of the Angiosperm Phylogeny Group classification for the orders and families of flowering plants: APG IV. Botanical Journal of the Linnean Society, 181(1): 1-20. doi: https://doi. org/10.1111/boj.12385

BELAY, B. (2009). Ethnomedicinal and floristic composition study of plants in Gullele Botanic Garden, Addis Ababa, Ethiopia. Unpublished Masters dissertation, Addis Ababa University.

BOTANIC GARDENS CONSERVATION INTERNATIONAL (2021). PlantSearch database. Available online: www.bgci.org/resources/ bgci-databases/plantsearch/ (accessed August 2021). 
BRAMWELL, B. \& LANE, B. (1993). Sustainable tourism: an evolving global approach. Journal of Sustainable Tourism, 1: 1-5. doi: https://doi. org/10.1080/09669589309450696

ERGUA, A., EPHREM, A., BELAY, B., YEMENZWORK, E. \& SETA, T. (2020). Floristic diversity and natural regeneration status of Entoto Mountain and the surrounding area in Addis Ababa, Ethiopia. International Journal of Forestry Research, 2020(2): 1-10. doi: https://doi. org/10.1155/2020/4936193

FEKADU, D., KUMERA, W. \& BELAY, B. (2011). Survey Report on Birds and Mammals of Gullele Botanic Garden, Addis Ababa, Ethiopia. Unpublished document.

GRATZFELD, J. (ED.) (2016). From Idea to Realisation - BGCl's Manual on Planning, Developing and Managing Botanic Gardens. Available online: https://www.bgci.org/files/ BG_Manual2017/cover\%20and\%20contents.pdf (accessed August 2021).

GULLELE BOTANIC GARDEN (2015). Gullele Botanic Garden Strategic Plan (2016-2020). Internal document.

HAILESELASSIE, G. \& GETANEH, A. (1989). The Addis Ababa-Nazaret volcanics: a MiocenePleistocene volcanic succession in the Ethiopian Rift. SINET: Ethiopian Journal of Science, 12(1): $1-24$.

HAWTHORNE, W.D. \& MARSHALL, C.A.M. (2016). A manual for Rapid Botanic Survey (RBS) and measurement of vegetation bioquality. Available online: https://herbaria.plants.ox.ac. uk/bol/Content/Projects/oxford/resources/
Rapid_Botanic_Survey_manual_2016.pdf (accessed August 2021).

HEDBERG, I., FRIIS, I. \& PERSSON, E. (2009). Flora of Ethiopia and Eritrea, Vol. 8. General Part and Index to Vols 1-7. The National Herbarium, Addis Ababa.

KITHIIA, J. \& LYTH, A. (2011). Urban wildscapes and green spaces in Mombasa and their potential contribution to climate change adaptation and mitigation. Environment and Urbanization, 23(1): 251-265. doi: https://doi. org/10.1177/0956247810396054

MOUNCE, R., SMITH, P. \& BROCKINGTON, S. (2017). Ex situ conservation of plant diversity in the world's botanic gardens. Nature Plants, 3: 795-802. doi: https://doi.org/10.1038/s41477-017-0019-3

SHAW, K. (2017). CEPF Small Grant Final Project Completion Report. Available online www.cepf. net/sites/default/files/final-report-sg72646.pdf (accessed August 2021).

SMITH, P.P. (2018). Building a global system for the conservation of all plant diversity: A vision for botanic gardens and Botanic Gardens Conservation International. Sibbaldia, 14: 5-13. doi: https://doi. org/10.24823/Sibbaldia.2016.208

WOLDEGERIMA, T., YESHITELA, K. \& LINDLEY, S. (2017). Ecosystem services assessment of the urban forests of Addis Ababa, Ethiopia. Urban Ecosystems, 20(3): 683-699. doi: https://doi. org/10.1007/s11252-016-0624-3

WYSE JACKSON, P.S. \& SUTHERLAND, L.A. (2000). International Agenda for Botanic Gardens in Conservation. Botanic Gardens Conservation International, Richmond.

\section{Appendix I Endemic plants in Gullele Botanic Garden}

\begin{tabular}{|c|c|c|c|}
\hline Botanical name & Habit & Family & Local name \\
\hline Acacia negrii Pic.-Serm. & Tree & Fabaceae & ก내 のடL \\
\hline Acanthus sennii Chiov. & Shrub & Acanthaceae & nก้กัก \\
\hline Alchemilla haumannii Rothm. & Herb & Rosaceae & PqPerc hí \\
\hline Aloe ankoberensis M.G. Gilbert \& Sebsebe & Succulent & Aloaceae & 267 \\
\hline Aloe benishangulana Sebsebe \& Tesfaye & Succulent & Aloaceae & 567 \\
\hline Aloe debrana Christian & Succulent & Aloaceae & 267 \\
\hline
\end{tabular}




\begin{tabular}{|c|c|c|c|}
\hline Botanical name & Habit & Family & Local name \\
\hline $\begin{array}{l}\text { Aloe gilbertii T.Reynolds ex Sebsebe \& } \\
\text { Brandham }\end{array}$ & Succulent & Aloaceae & 玄67 \\
\hline Aloe kefaensis M.G. Gilbert \& Sebsebe & Succulent & Aloaceae & 玄67 \\
\hline Aloe percrassa Tod. & Succulent & Aloaceae & 玄6午 \\
\hline Aloe pirottae A. Berger & Succulent & Aloaceae & 玄67 \\
\hline Aloe pulcherrima M.G. Gilbert \& Sebsebe & Succulent & Aloaceae & 内市玄67 \\
\hline Aloe schelpei Reynolds & Succulent & Aloaceae & 玄67 \\
\hline Aloe sinana Reynolds & Succulent & Aloaceae & 玄67 \\
\hline Aloe steudneri Schweinf. & Succulent & Aloaceae & 玄6午 \\
\hline Aloe tewoldei M.G. Gilbert \& Sebsebe & Succulent & Aloaceae & 玄67 \\
\hline Aloe trigonantha L.C. Leach & Succulent & Aloaceae & 玄67 \\
\hline Aloe yavellana Reynolds & Succulent & Aloaceae & 玄67 \\
\hline Chiliocephalum schimperi Benth. & Herb & Asteraceae & $\lambda ל$ त $^{\prime}$ \\
\hline Cineraria abyssinica Sch.Bip. ex A.Rich. & Herb & Asteraceae & de बव $C 6$ \\
\hline Commiphora monoica Vollesen & Tree & Burseraceae & \\
\hline Crotalaria exaltata Polhill & Shrub & Fabaceae & 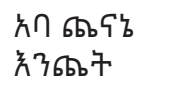 \\
\hline $\begin{array}{l}\text { Crotalaria rosenii (Pax) Milne-Redh. ex } \\
\text { Polhill }\end{array}$ & Shrub & Fabaceae & 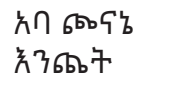 \\
\hline Cyanotis polyrrhiza Hochst. ex Hassk. & Herb & Commelinaceae & \\
\hline Echinops kebericho Mesfin & Shrub & Asteraceae & 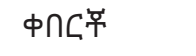 \\
\hline Echinops longisetus A.Rich. & Shrub & Asteraceae & \\
\hline Eragrostis tef (Zucc.) Trotter & Herb & Poaceae & ๓ఢ \\
\hline Erythrina brucei Schweinf. & Tree & Fabaceae & $h C$ 㠳 \\
\hline Erythrina burana Chiov. & Tree & Fabaceae & $n C$ 吊 \\
\hline Euphorbia awashensis M.G. Gilbert & Shrub & Euphorbiaceae & \\
\hline Euphorbia baleensis M.G. Gilbert & Shrub & Euphorbiaceae & \\
\hline Euphorbia betulicortex M.G. Gilbert & Tree & Euphorbiaceae & \\
\hline Helichrysum harennensis Mesfin & Herb & Asteraceae & \\
\hline Hypericum gnidiifolium A.Rich. & Shrub/tree & Hypericaceae & \\
\hline Impatiens rothii Hook.f. & Herb & Balsaminaceae & \\
\hline $\begin{array}{l}\text { Impatiens tinctoria A.Rich. subsp. abyssinica } \\
\text { (Hook.f.) Grey-Wilson }\end{array}$ & Herb & Balsaminaceae & \\
\hline Inula confertiflora A.Rich. & Shrub & Asteraceae & \\
\hline Jasminum stans Pax & Shrub & Oleaceae & 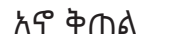 \\
\hline
\end{tabular}




\begin{tabular}{|c|c|c|c|}
\hline Botanical name & Habit & Family & Local name \\
\hline Kalanchoe petitiana A. Rich. & Herb & Crassulaceae & 去々号U入 \\
\hline Kniphofia foliosa Hochst. & Herb & Asphodelaceae & 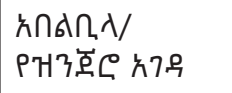 \\
\hline Kniphofia hildebrandtii Cufod. & Herb & Asphodelaceae & \\
\hline Kniphofia insignis Rendle & Herb & Asphodelaceae & \\
\hline Kniphofia schimperi Baker & Herb & Asphodelaceae & 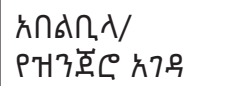 \\
\hline $\begin{array}{l}\text { Laggera tomentosa (Sch.Bip. ex A.Rich.) Oliv. } \\
\text { \& Hiern }\end{array}$ & Herb & Asteraceae & hnhn \\
\hline Leucas stachydiformis (Hochst. ex Benth) Briq. & Herb & Lamiaceae & \\
\hline Lippia adoensis Hochst. ex Walp. & Shrub & Lamiaceae & hウட社 \\
\hline Lobelia rhynchopetalum Hemsl. & Shrub & Lobeliaceae & 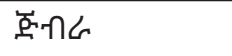 \\
\hline Maytenus addat (Loes.) Sebsebe & Tree & Celastraceae & hחた \\
\hline Mikaniopsis clematoides (A.Rich.) Milne-Redh. & Climber & Asteraceae & 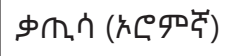 \\
\hline Millettia ferruginea (Hochst.) Bak. & Tree & Fabaceae & नीCमीL \\
\hline Peucedanum mattirolii Chiov. & Herb & Apiaceae & $\mu<-$-ीH \\
\hline Phagnalon abyssinicum Sch.Bip. ex A.Rich & Herb & Asteraceae & 3नीรกள \\
\hline $\begin{array}{l}\text { Phragmanthera macrosolen (A.Rich.) M.G. } \\
\text { Gilbert }\end{array}$ & Parasitic & Loranthaceae & \\
\hline $\begin{array}{l}\text { Plectocephalus varians (A.Rich.) C.Jeffrey ex } \\
\text { Cuf. }\end{array}$ & Herb & Asteraceae & 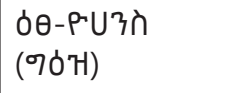 \\
\hline $\begin{array}{l}\text { Rhus glutinosa A.Rich. subsp. neoglutinosa } \\
\text { (M.G. Gilbert) }\end{array}$ & Shrub & Ananthaceae & 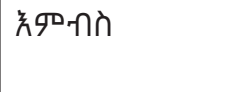 \\
\hline Satureja paradoxa (Vatke) Engler ex Seybold & Herb & Lamiaceae & \\
\hline Senecio myriocephalus Sch.Bip. ex A.Rich. & Herb & Asteraceae & 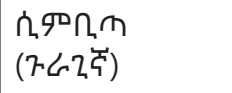 \\
\hline Senecio ochrocarpus Oliv. \& Hiern & Herb & Asteraceae & 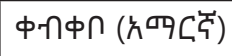 \\
\hline Senecio schimperi Sch.Bip. & Herb & Asteraceae & 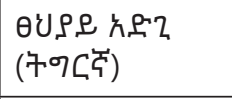 \\
\hline Sideroxylon oxyacanthum Baill. & Shrub/tree & Sapotaceae & \\
\hline Solanecio gigas (Vatke) C.Jeffrey & Shrub & Asteraceae & 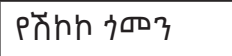 \\
\hline Taverniera abyssinica A.Rich. & Shrub & Fabaceae & P-37+芹 \\
\hline Thymus schimperi Ronniger & Herb & Lamiaceae & mกे⿱ \\
\hline Trifolium calocephalum Fresen. & Herb & Fabaceae & \\
\hline Urtica simensis Steudel & Herb & Urticaceae & ウंव्प \\
\hline Vernonia leopoldii (Sch.Bip.) Vatke & Shrub & Asteraceae & 7 宦 \\
\hline
\end{tabular}

Source: Hedberg et al. (2009). 


\section{Appendix II Large mammals in Gullele Botanic Garden}

\begin{tabular}{|c|l|l|l|l|}
\hline No. & \multicolumn{1}{|c|}{ English name } & \multicolumn{1}{c|}{ Order } & \multicolumn{1}{c|}{ Family } & \multicolumn{1}{c|}{ Scientific name } \\
\hline 1 & Common duiker & Artiodactyla & Bovidae & Sylvicapra grimmia \\
\hline 2 & Minilik bushbuck & Artiodactyla & Bovidae & $\begin{array}{l}\text { Tragelaphus seriptus } \\
\text { meneliki }\end{array}$ \\
\hline 3 & African civet & Carnivora & Viverridae & Civettictis civetta \\
\hline 4 & Golden jackal & Carnivora & Canidae & Canis aureus \\
\hline 5 & Serval cat & Carnivora & Felidae & Leptailurus serval \\
\hline 6 & Spotted hyena & Carnivora & Hyaenidae & Crocuta crocuta \\
\hline 7 & White-tailed mongoose & Carnivora & Herpestidae & Ichneumia albicauda \\
\hline 8 & Abyssinian hare & Lagomorpha & Leporidae & Lepus habessinicus \\
\hline 9 & Vervet monkey & Primates & Cercopithecidae & Chlorocebus pygerythrus \\
\hline 10 & Crested porcupine & Rodentia & Hystricidae & Hystrix cristata \\
\hline 11 & Aardvark & Tubulidentata & Orycteropodidae & Orycteropus afer \\
\hline
\end{tabular}

Source: Fekadu et al. (2011).

\section{Appendix III Endemic bird species in Gullele Botanic Garden}

\begin{tabular}{|c|l|l|l|l|}
\hline No. & English name & Order & Family & Scientific name \\
\hline 1 & White-collared pigeon & Columbiformes & Columbidae & Columba albitorques \\
\hline 2 & Abyssinian oriole & Passeriformes & Oriolidae & Oriolus monacha \\
\hline 3 & Thick-billed raven & Passeriformes & Corvidae & Corvus crassirostris \\
\hline 4 & White-backed black tit & Passeriformes & Paridae & Melaniparus leuconotus \\
\hline 5 & White-winged cliff chat & Passeriformes & Muscicapidae & Myrmecocichla semirufa \\
\hline 6 & Rüppell's robin chat & Passeriformes & Muscicapidae & Cossypha semirufa \\
\hline 7 & Abyssinian catbird & Passeriformes & Sylviidae & Parophasma galinieri \\
\hline 8 & Abyssinian slaty & Passeriformes & Muscicapidae & $\begin{array}{l}\text { Melaenornis } \\
\text { chocolatinus }\end{array}$ \\
\hline 9 & White-billed starling & Passeriformes & Sturnidae & $\begin{array}{l}\text { Onychognathus } \\
\text { albirostris }\end{array}$ \\
\hline 10 & Wattled ibis & Pelecaniformes & Threskiornithidae & Bostrychia carunculata \\
\hline 11 & Banded barbet & Piciformes & Lybiidae & Lybius undatus \\
\hline 12 & Abyssinian woodpecker & Piciformes & Picidae & Dendropicos abyssinicus \\
\hline 13 & Black-winged lovebird & Psittaciformes & Psittaculidae & Agapornis taranta \\
\hline
\end{tabular}

Source: Debushe et al. (2011). 